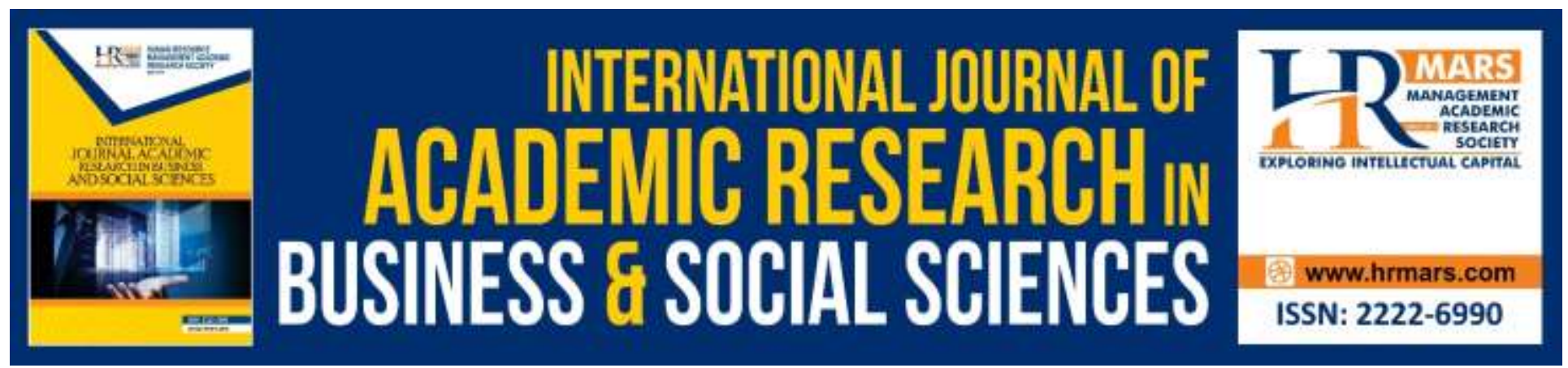

\title{
Strategic Management Practices by Beach Management Units in Bondo Sub County, Kenya
}

\author{
Ncurai M. Dennis, Aketch Ng'ong'a, Odero Auma Faith
}

To Link this Article: http://dx.doi.org/10.6007/IJARBSS/v9-i10/6484

DOI: $10.6007 /$ IJARBSS/v9-i10/6484

Received: 05 August 2019, Revised: 19 September 2019, Accepted: 01 October 2019

Published Online: 24 October 2019

In-Text Citation: (Dennis, Ng'ong'a, \& Faith, 2019)

To Cite this Article: Dennis, N. M., Ng'ong'a, A., \& Faith, O. A. (2019). Strategic Management Practices by Beach Management Units in Bondo Sub County, Kenya. International Journal of Academic Research in Business and Social Sciences, 9(10), 229-241.

Copyright: (c) 2019 The Author(s)

Published by Human Resource Management Academic Research Society (www.hrmars.com)

This article is published under the Creative Commons Attribution (CC BY 4.0) license. Anyone may reproduce, distribute, translate and create derivative works of this article (for both commercial and non-commercial purposes), subject to full attribution to the original publication and authors. The full terms of this license may be seen

at: http://creativecommons.org/licences/by/4.0/legalcode

Vol. 9, No. 10, 2019, Pg. 229 - 241

http://hrmars.com/index.php/pages/detail/IJARBSS

JOURNAL HOMEPAGE

Full Terms \& Conditions of access and use can be found at http://hrmars.com/index.php/pages/detail/publication-ethics 


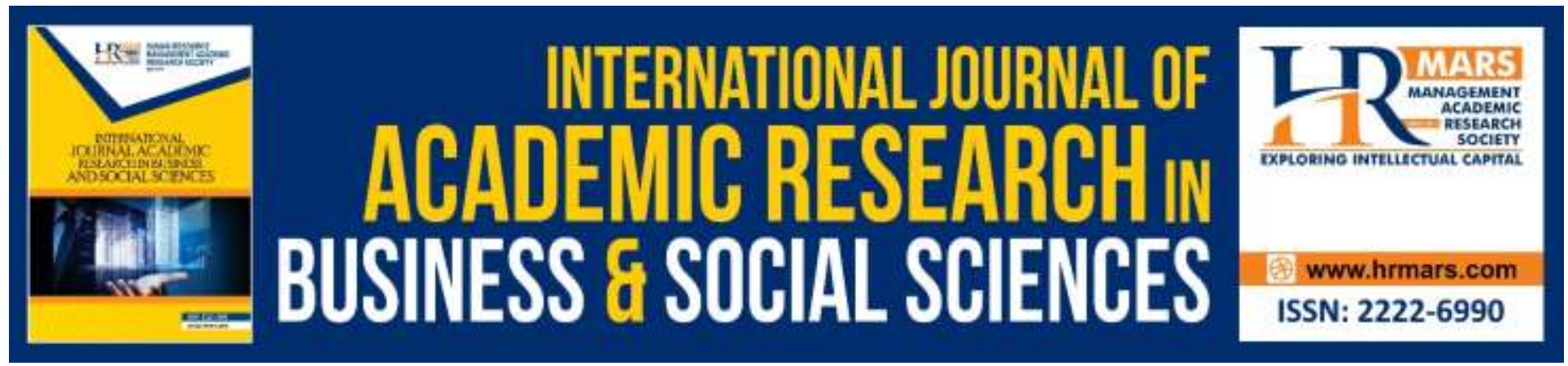

\title{
Strategic Management Practices by Beach Management Units in Bondo Sub County, Kenya
}

\author{
Ncurai M. Dennis \\ PhD Candidate, Jomo Kenyatta University of Agriculture and Technology, Kenya \\ Email:dceem@gmail.com
}

Aketch Ng'ong'a, PhD

Email:aketchngonga@yahoo.com

Odero Auma Faith

PhD Student, University of Nairobi, Kenya

Email:faiodero07@gmail.com

\begin{abstract}
Modern organizations are constantly interacting with competitive and turbulent market places presenting new threats and opportunities. This calls upon the organizations to engage in strategic management practices in order to survive and achieve their corporate goals. The objective of this study was to determine the strategic management practices adopted by Beach Management Units in Bondo Sub County in Kenya. A descriptive cross-sectional survey design was adopted. This was a census survey of all the 42 units operating in Bondo. The study established that more than $30 \%$ of the studied organizations adopted most of the strategic management practices. These organizations had vision, mission statements and core values which were mainly implied. To larger extent situation analysis, setting of financial objectives, crafting and implementation of strategies and continuous evaluation and control were adopted. The study advances adoption of the strategic management practices by small organizations to remain both efficient and effective. In future research should be conducted on factors influencing and challenges of strategy implementation with respective to community owned organizations like BMUs.
\end{abstract}

Keywords: Strategic Management Practices, Beach Management Units (BMUs)

\section{Background of the Study}

The modern organizations are continuously faced with environmental challenges that must be anticipated and incorporated into daily decision making process. Kenyan organizations are no exception, they are in constant interactions with competitive and turbulent marketplaces which 
have created new behaviors and opportunities (Kotler, 2006). Kasele (2011) suggests that different types of organizations have found it necessary in recent years to engage in practices of strategic management for their corporate survival and achieve their corporate goals. Pearce and Robinson (2011), notes that adoption of the strategic management practices facilitate optimal positioning of the organization in their competitive environment

All organizations depend on and serve the environment in equal measure. Organizations as systems have to interact and network with the environment to fiercely compete with other industry players. The management must be open to the reality of predicting or reacting to environmental changes within which they exist; failure to which any disturbance might alter the balance on any part of the system. The environmental imbalances within an industry bring about the competition. Organizations must examine the industry forces that drive competition (Mazzarol \& Rebound, 2009). The market analysis informs the organizations their relative position that contributes sustainable profits through efficient allocation of resources.

Fisheries resources in Kenya are important sources of food, employment and foreign exchange. Driven by a $6 \%$ Gross Domestic Product growth rate in recent years and changing consumer habits, fish has become an increasingly important part of the Kenyan household's diet, both directly and indirectly (Government of Kenya, 2010). The Beach Management Units (BMUs) are the key industry players that are involved in the effective co-management of fisheries in Lake Victoria. However, the industry remains lowly prioritized by the policy makers; lack coherent development plan and low priority given to the sector in terms of resource allocation has adversely affected its growth and performance (Government of Kenya, 2010). The industry players must now embrace strategic management practices to make sense of an uncertain, complex and fast changing world around them.

\section{Purpose of the Study}

The objective of this study was:-

(i)To determine the strategic management practices adopted by Beach Management Units in Bondo Sub County, Kenya.

\section{Research Problem}

Strategic management is largely associated with the large corporation and most of the theories associated with the subject have been developed for large firms (Mazzarol \& Rebound, 2009). The argument is that small organizations are generally led by management who make strategic decisions based more on intuition rather than academic principles. Kasele (2011) and Lynch (2009) argue that strategic management is also applicable to smaller organizations especially when seeking financing. Small organizations require strategic management to enhance their performance by creating and shaping effective strategies. Effective strategic management is essential for small organizations to cope with increasing competition and business complexity (Barbe, Dewhurst, Munive-Hernandez, \& Pritchard, 2004).

Beach Management Units are in constant interaction with the external environment in which they exist. Their existence is endangered by declining fish stocks and ineffective fisheries laws and policies. Their formation was a response to declines in fish stocks and decreasing aquatic biodiversity (Jaeckel \& Ngige, 2007); the rationale behind their formation was to integrate local and national management to achieve sustainable management of aquatic biodiversity, making 
use of both traditional knowledge and modern scientific findings. The current crop of management needs to embrace strategic management practices to ensure achieving their performance objectives.

A number of studies have been done on the strategic management practices in different contexts (Ogollah, 2007; Mosiah, 2008; Maina, 2009; Kazaz \& Ulubeyli, 2009; Pamulu, 2010; Odunga, 2011; Mbondo, 2011; Oluoch, 2011; Waithira, 2011; and Ngatia, 2011 among others). None of these studies have focused on community owned organizations managed by democratically elected leadership in the fisheries industry. Due to contextual and managerial differences in the above studied contexts, their findings on strategic management practices cannot be generalized to represent the strategic management practices by BMUs. To bridge the existing knowledge gap, this study focused on the strategic management practices by Beach Management Units.

\section{Significance of the Study}

Beach Management Units policy makers in Bondo will benefit from the findings of this study in formulation and implementation of policies related to strategic management practices. Bondo Sub county Government will also find the study useful in making policies, rules and regulations that governs Beach management Units to protect investors and fishermen from external forces that would deprive them of their livelihood and support the communities living near the beaches by giving them soft loans and grants to promote the economic activities within the beach management units. The findings will make them to further understand the challenges in implementing strategic management practices so that they can be able to address by involving everybody through participation and education. In addition, scholars and researchers will find the study findings useful for current and further research in strategic management practices by Beach Management Units in Bondo Sub-County in Kenya.

\section{Theoretical Underpinnings}

The concept of strategic management did not appear overnight (Freeman et al., 2009), it evolved over time. The evolution of strategic management can be traced from developing of strategic plans and acting on them. This evolution is credited to Alfred Chandler and Charles Hofer whom focused on goal setting, strategy formulation, administration and strategic control as key elements of strategic management process. Since then, strategic management has become an academic discipline in its own right, like marketing and finance (Ahlstrand et al., 1998). The field has really evolved from the writing by Sun Tzu on the Art of War in about the fourth century B.C and many other authors.

Strategic management has many different definitions. Pearce and Robinson (2011), defines strategic management as a set of decisions and actions that result in the formulation and implementation of plans designed to achieve a company's objectives. Johnson et al. (2011) views strategic management as a process of understanding the strategic position of an organization, strategic choices for the future and turning strategy into action. In response to different definitions, Chen, Hambrick and Nag (2007) concluded that strategic management deals with the major intentions and emerging initiatives taken involving utilization of firm's resources to enhance the organizational performance in their external environment. The definition qualifies the concept of strategic management has a sense of purpose, looking ahead, planning, positioning, strategic fit, leverage and stretching to gain sustainable competitive advantage. 
Therefore, strategic management is as a systematic approach applicable within different contexts involving planning and putting into action the strategic decisions for the survival of the organization.

Central to strategic management is the concept of strategy. Johnson et al. (2011) view strategy as a long term direction of an organization which defines the purpose of the organization and creates a competitive advantage over its competitors. Organizations position within external environment by configuring its resources and competences to fulfill stakeholder's expectations. Mintzberg (1987) defines strategy from a 5Ps approach: a plan, ploy, pattern, position and perspective while Pearce and Robinson (2011) consider strategy as a game plan of an organization which provides a framework for managerial decisions. As any in any game the organization must deploy its resources to ensure it outwit other competitors.

Organizations whether small or large differ on their strategy development processes because they operate in a different environment. Mintzberg and Waters (1985) points that strategy formation walks on two feet, one deliberate, and the other emergent. They resolve that the management requires a light deft touch-to direct in order to realize intentions while at the same time responding to an unfolding pattern of action. For small organizations the likelihood of engaging in emergent strategy is high while within large corporations are likely to engage in deliberate strategy.

Pearce and Robinson (2011) equate strategic management to participatory decision making process. It is a decision making hierarchy process involving corporate, business, functional levels of an organization. At each level strategic choices are made which aid in positioning and relating the firm to its environment to assure its continued success (Ansoff \& McDonell, 1990). A formalized planning process is necessary to induce managers to think seriously about long-term strategy for the organization or operating unit (Cohen \& Cyert, 1973). However, success or failure in strategy implementation is dependent on how management communicates clearly and persuasively to all organizational members the commitment and attitudinal change required to carry out the strategy and meet desired performance targets.

The strategic management practices are more than just a set of guidelines to follow. It involves both strategic thinking by top management, then the application of such thought to a process. Strategic management practices are the direct organizational application of the concepts of business strategy that have been developed in the academic realm to maximize the utilization of resources in relation to objectives. Successful implementation relies on better understanding of such concepts by everyone within the firm.

Pearce and Robinson (2011) alludes that strategic management process involves two broad phases: strategic formulation and strategy implementation. However according to Lynch (2009), strategic management process has three sequential core areas: strategic analysis, strategic development and strategic implementation. Kasele (2010) concurs that strategic management process is composed of three major phases: Formulation, Implementation and Evaluation. It is within these three phases the elements of strategic management practice are found. For larger organizations the expectation would be adoption of most of the practices of strategic management. Similarly, community owned organizations would be expected to have adopted in smaller extent. 


\section{Methodology of the Study}

The study employed a descriptive cross-sectional survey. It was a census survey as it focused on 42 registered BMUs in Bondo Sub County. All of them were contacted with 28 responding to the study. To determine the objective of the study, a number of practices depicting strategic management process were contextualized and presented to the respondents through a selfadministered questionnaire. Respondents were the management committee who were considered well versed with their organization and changes in the industry. The study used quantitative data which was analyzed using descriptive statistics. Descriptive statistics enable meaningful description of a distribution of scores or measurements using a few indices or statistics (Mugenda \& Mugenda, 1999). The standard deviation and mean scores were used to show the distribution of the findings.

\section{Study Findings}

For purposes of this study, standard deviations greater than 1.00 were given to designate a high dispersion around the mean while those below 1.00 were given to designate a relatively high clustering around the mean. The former implies that the respondents differed widely on how they rated the given aspect while the latter implies that they gave largely similar ratings.

\section{Respondent Profile}

$50 \%$ of the organizations have been in existence for over 15 years. Further, findings indicate that $78.6 \%$ of the organizations had more than 30 members. The longevity and membership were employed as a measure of growth and size.

\section{Strategic Direction}

Majority (67.9\%) of the BMUs had vision and mission statements values which were implied with $32.1 \%$ of the organizations indicated that they have a written down. This is in line with Kathuri's (2005) argument that a large proportion of the organizations do not prepare written components of the strategic direction. The development of the vision and mission statements in $35.8 \%$ organizations is done by both the management and other members.

\section{Situation Analysis}

Table 1 show that the overall mean score of the extent to which business environment is analyzed is at 3.42, meaning that most units conduct business environment analysis to a moderate level. An analysis of regulatory-legal factors, Industry competition, management style and client purchasing power with respective mean values of 3.93, 3.86, 3.75 and 3.71 were considered to moderate level. The factors which were ranked as having minimal influence include the composition of customers, organizational culture, change of political leadership and cultural factors with respective mean scores of 3.32, 3.04, 2.96 and 2.43. Their standard deviations range from low to high an indication of diverging responses. 
Table 1: The extent at which factors of environment are analyzed

\begin{tabular}{|l|c|c|}
\hline Factor & Mean & S.D \\
\hline $\begin{array}{l}\text { Existing policies or laws on fishing activities and environmental } \\
\text { conservation }\end{array}$ & 3.93 & 1.303 \\
\hline Industry Competition & 3.86 & 1.079 \\
\hline Management style of BMU committee & 3.75 & .928 \\
\hline Purchasing power customers & 3.71 & .976 \\
\hline Making comparison of past and current performance & 3.64 & 1.096 \\
\hline Changing fish stock levels in the Lake & 3.61 & 1.343 \\
\hline $\begin{array}{l}\text { Assessing the competencies, capabilities and resource strengths in the } \\
\text { BMU }\end{array}$ & 3.54 & 1.201 \\
\hline Your competitive position in relation to other BMUs & 3.46 & 1.138 \\
\hline Loss of habitat and biodiversity & 3.39 & 1.423 \\
\hline Uptake of new or modern fishing methods/equipments & 3.36 & 1.339 \\
\hline Accessibility of financial facilities for the BMU & 3.36 & .989 \\
\hline The composition of your customers & 3.32 & 1.096 \\
\hline The organizational culture/shared values of the BMU & 3.04 & 1.232 \\
\hline Change of political leadership & 2.96 & 1.347 \\
\hline Changing eating habits or preference for fish & 2.43 & 1.2 \\
\hline Overall Mean Score & 3.42 & \\
\hline
\end{tabular}

33.3\% of the BMUs use SWOT analysis. Those critical issues that require immediate action are highly prioritized and were considered to have the greater degree of priority. It can be concluded that only the BMUs that use SWOT are able to prioritize strategic issues arising from environmental analysis.

\section{Setting Objectives}

Majority of BMUs sets financial objectives with a mean of 4.32. A standard deviation of 0.819 implies that a close agreement in responses. The overall mean score of 3.6 suggests that most of the units sets objectives at a moderate level.

Table 2: Setting of objectives

\begin{tabular}{|l|c|c|}
\hline Response & Mean & Std. Dev. \\
\hline Financial Objectives & 4.32 & 0.819 \\
\hline Short term objectives & 3.54 & 0.999 \\
\hline Long term objectives & 3.36 & 0.989 \\
\hline Non-financial objectives & 3.18 & 1.09 \\
\hline Overall Mean Score & $\mathbf{3 . 6}$ & \\
\hline
\end{tabular}

Findings suggest that setting of the organizational objectives is mainly done by the management and communicated through meetings at $89.3 \%$. This suggests that the organization creates awareness amongst its members of the set performance objectives and targets. 
INTERNATIONAL JOURNAL OF ACADEMIC RESEARCH IN BUSINESS AND SOCIAL SCIENCES Vol. 9, No. 10, October, 2019, E-ISSN: 2222-6990 @ 2019 HRMARS

\section{Strategic Development Process}

Strategies are developed through both formal and informal process in majority of the BMUs (60.7\%). This proposition suggests that the strategies are normally developed through both formal and informal process by the management, select members and with minimal assistance of external consultants in some cases.

Table 3: Strategy Development Process

\begin{tabular}{|l|c|c|}
\hline Response & Frequency & Percentage \\
\hline Through both formal and informal process & 17 & 60.7 \\
\hline Through a formal strategic planning process & 8 & 28.6 \\
\hline Through an informal process & 2 & 7.1 \\
\hline Non response & 1 & 3.6 \\
\hline Total & $\mathbf{2 8}$ & $\mathbf{1 0 0 . 0}$ \\
\hline
\end{tabular}

\section{Strategic Analysis and Choice}

Table 4 indicates an overall mean score of 3.16, meaning that strategies activities undertaken were analyzed and chosen at a moderate level. Differentiation (3.93), cooperation (3.93), and market and product development (3.79) were the main strategies undertaken at moderate level. Low cost strategies are undertaken to a very small extent with a mean score of 1.68. The standard deviation gave the deviations of various responses from the mean; in the case of choice of low cost strategy implies that a close agreement in responses. In case of diversification and focus strategy, there were divergent opinions as shown by Std. 1.524 and 1.574 since respondents gave non-consistent responses.

Table 4: The strategic activities undertaken

\begin{tabular}{|l|l|l|}
\hline Response & $\begin{array}{l}\text { Mea } \\
\mathbf{n}\end{array}$ & $\begin{array}{l}\text { Std. } \\
\text { Dev. }\end{array}$ \\
\hline $\begin{array}{l}\text { Selling the best fish capture to your customers at a higher price } \\
\text { (differentiation) }\end{array}$ & 3.93 & 1.086 \\
\hline Cooperating with other BMUs & 3.93 & 1.016 \\
\hline Looking for new markets/customers (market and product development) & 3.79 & 1.315 \\
\hline Engaging in other income generating activities (diversification) & 3.21 & 1.524 \\
\hline Selling fish to loyal customers only (focus strategy) & 2.43 & 1.574 \\
\hline Lowering the price of fish to sell to more customers (low cost) & 1.68 & 0.945 \\
\hline Overall Mean Score & 3.16 & \\
\hline
\end{tabular}




\section{Strategy Implementation}

Findings in table 5 indicate various factors that affect strategy implementation differently. An overall mean score of 3.36 implies the extent at which cross sectional of factors affect implementation of action plan. Stakeholder Involvement (3.89), proper utilization of resources (3.82) and effective communication channels (3.75) were the major factors that affect implementation of action plan to a moderate level. Capacity building (2.68) and rewards initiatives (2.29) affect the implementation of action plan in small extent. The standard deviation gave the deviations of various responses from the mean; the high deviations indicate the divergent opinions.

Table 5: The extent at which factors affect implementation of action plan

\begin{tabular}{|l|c|c|}
\hline \multicolumn{1}{|c|}{ Factor } & Mean & Std. Dev. \\
\hline Involving stakeholders in the implementation of planned activities & 3.89 & 1.37 \\
\hline Ensuring proper utilization of funds & 3.82 & 1.467 \\
\hline Communicating effectively to all members & 3.75 & 1.456 \\
\hline Existing BMU organizational structure & 3.64 & 1.521 \\
\hline Provision of adequate leadership direction & 3.54 & 1.453 \\
\hline Establishing best practices and continuous improvement & 3.36 & 1.393 \\
\hline Distribution of decision making authority & 3.32 & 1.701 \\
\hline Use of adequate/appropriate fishing facilities/equipments & 3.29 & 1.512 \\
\hline Capacity building and training the BMU members & 2.68 & 1.565 \\
\hline Rewarding members who excel in your planned activities & 2.29 & 1.436 \\
\hline Overall Mean Score & $\mathbf{3 . 3 6}$ & \\
\hline
\end{tabular}

\section{Strategy Evaluation and Control}

89.3\% of the organizations studied compare past with present performance and periodically takes corrective action taken when variance arise. This is a suggestion that BMUs monitor and compare actual performance with desired performance which to ensure that implementation of strategies is on track through a participatory approach.

\section{Discussion and Findings}

The study findings established that majority of the BMUs have adopted most of the strategic management practices. It is evident that all the tasks of the strategic management that were presented to the respondents are applicable to them. The findings largely confirm the definition of the strategic management process as provided by Freeman et al. (2009), Lynch (2009), Johnson et al., (2011) and Pearce and Robinson, (2011).

The longevity of the organizations is expected to portray to have a larger market share and a more formalized way of conducting business operations and innovated ways of handling organizational challenges. The membership of the BMU has a bearing on the size of an organization in respect to wealth and resource availability for growth and development.

The study reveals that just like in corporate world, BMUs set strategic direction to envision what the organization wants to be and its future achievements. The components of strategic direction are mainly developed by the management. However, there are instances where the input of external consultant was sought. The components of strategic direction are mainly 
communicated throughout the organization through meetings. This is important to ensure all members understand the direction the organization is moving and provides guidance for developing objectives. High non response rate was noted especially in setting of formally documented strategic direction. This implies that the vision, mission and core values are mainly implied in nature.

The findings reveal that organizations consider their external and internal environment during decision making process. Regulatory-legal factors, Industry competition, management style and client purchasing power have greater degree of influence. BMUs by their nature are political entities established by BMU regulations of 2007; the committee is elected through a democratic process as outlined in the regulations. BMUs were established against the background of declining fish stocks and ineffective fisheries laws and policies (Jaeckel \& Ngige, 2007). Due to declining fisheries capture, market share and buyers behavior has increased competition within the industry. Hence, environmental analysis aids in assessing conditions and trends in the organization's environment and their implications. This suggests that BMUs conduct external and internal analysis with a view of taking advantage of available opportunities through proper utilization of strengths.

Adoption of SWOT analysis aids in identification of organizational internal strengths and weaknesses, and external opportunities and threats. Majority of the organizations adopt SWOT analysis to prioritize the critical issues that require immediate action. The prioritized critical issues are used to set performance objectives. The study reveals that none of the organization had documented this framework. This confirms the nature of strategic planning by informal organizations.

BMUs set organizational objectives to align the firm's strengths and weaknesses to the environmental opportunities and threats. Financial objectives are considered a priority. This suggests that the organizations pay little attention to other type of objectives which are key to achievement of business goals. Standard deviations of less than 1 , confirms similar opinion shared by different organizations. The studied organizations embrace both formal and informal strategy development process with differentiation, cooperation among the competitors, market and product development and diversification being the major strategies formulated to achieve the set objectives.

The studied organizations developed action plans to aid in implementation of the crafted strategies. Stakeholder involvements, Proper utilization of resources and effective communication channels have a higher extent of affecting implementation of action plan because they are provided for by the BMU regulations of 2007. Majority of the organizations (89.3\% and $78.6 \%$ ) indicated that they compare past with present performance and takes corrective action when any variance arises. It is significant to note that throughout the strategic management practices adopted by BMUs studied; all the members were involved and communicated to different degrees through various modes.

The findings confirms that strategic management involves a process that entails forming a strategic vision and stating the mission to bring about the sense of purpose into a firm's activities and providing long term direction and scope for the organization; environmental analysis to identify opportunities and threats in the environment and strengths and weaknesses of the organization; setting measurable objectives to address environmental opportunities and threats as well as the strengths and weaknesses of the organization and crafting strategies to achieve the set objectives; implementing and executing strategy, evaluating performance, reviewing new developments and initiating corrective adjustments 
when necessary. The study reveals that the studied organizations mainly deal with a single product and specified market hence embracing a simplified strategic management practices with varied degree of formalization.

The findings also affirm the formality aspect of strategic management as pointed out by Mital et al. (2011), which cites complexity in products or markets, technology, performance and competition among the factors influencing formality of the strategic management. The study found out that majority of the organizations is engaged in informal strategic management. Further, the findings confirm the contribution by Mazzarol and Rebound (2009) that the strategic management practices for small organizations due to their nature are likely to be involved in informal strategic management.

\section{Conclusion and Recommendations Conclusion}

The study established that to a greater extent majority of the studied organizations have embraced both formal and informal practices of the strategic management. Johnson et al. (2011) affirms that just like corporate organizations, BMUs are continuously faced with environmental challenges. They are constantly interacting with competitive and turbulent marketplaces which have created new behaviors and opportunities (Kotler, 2006). Therefore, BMUs must adopt strategic management practices so that they position optimally in their competitive environment; for survival and achievement of their business goals (Pearce and Robinson, 2011).

Like any small organization, BMUs develop vision and mission statements which are mainly implied and developed by the management with minimal involvement of all other members and external consultants. Situation analysis, setting of objectives and crafting strategies to achieve the set objectives and continuously monitoring and evaluation were undertaken to varied degrees though informally.

Finally, it is evident that most of the practices of strategic management were manifested in the studied organizations. The findings confirm that the strategic management practices for small organizations primarily follow emergent approach due to emerging opportunities and entrepreneurial nature of the management (Mazzarol \& Rebound, 2009). Strategic management provides an organization with consistency of action (Byars, et.al, 1996) and ensures all levels of organization are brought on board by encouraging commitment. It is evident that strategic planning tends to be more informal in community owned organizations like BMUs, though it is necessary and valuable.

\section{Contribution of the Study to the Body of Knowledge, Theory and Practice}

The study used structured and unstructured questionnaire. Past studies ignored the relationship between strategic management practices and beach management units. The research gap was addressed by administering questionnaires to the 42 registered BMUs Secretaries who were well versed with their units and the changes taking place in the industry then conducting quantitative analysis. The study findings shows that strategic management practices was not fully adopted by Beach Management Units in Bondo Sub County, Kenya.

\section{Recommendations of the Study}

The findings indicate that majority of the BMUS had adopted most of the strategic management practices to less extent. To maintain and sustain competitive edge they have to 
respond to emerging environmental challenges. It is recommended that the BMUs should fully embrace strategic management practices for their survival.

The policy makers within fisheries sub sector should formulate and implement sound policies and effective laws that will tap the potential of the industry. The industry is faced with myriad of challenges. The interventions should be anchored on adoption of strategic management practices by relevant state agencies.

\section{Limitation of the Study}

The study only targeted BMUs in Bondo Sub County only. This contextual limitation means that the findings of this study might not apply to those operating in other regions. Secondly, there is an inherent limitation of respondents' bias and subjectivity in providing responses to the questionnaire items. Further, the researcher targeted the management however in some instances other members participated. It is also not possible to ascertain whether the targeted respondents were the ones who actually filled the questionnaire. Finally, the study employed a descriptive cross-sectional survey design. Questionnaire was used to gather primary data. Reliance on only questionnaire implies that the data collected could not be verified by other data collection techniques.

\section{Suggestions for Further Research}

Future studies should find out the challenges of strategic formulation and implementation for community owned organizations. There is a need to replicate the same study in other regions in order to validate the current study's findings. This will make generalization of the research findings possible and address the limitations of non-response. Further, in the future studies, other data collection techniques should be incorporated to verify and validate the responses.

\section{References}

Ahlstrand, B., Lampel, J. \& Mintzberg, H. (1998). Strategy Safari: A Guided Tour through the Wilds of Strategic Management. New York: The Free Press.

Ansoff, I., \& McDonnel, E. (1990). Implanting Strategic Management (2 ${ }^{\text {nd }}$ Ed.). India: Prentice Hall.

Aosa, E. (2011). Strategic management within Kenya Firms. DBA Africa Management Review, 1(1):25-36.

Cohen, K. J., \& Cyert, R. M. (1973). Strategy Formulation, Implementation and Monitoring. Journal of Business, 46(3): 349-367.

Cooper, D. R., \& Schindler, P. S. (2006). Business Research Methods (9 $9^{\text {th }}$ Ed.). New York: McGraw

Hill.

Fisheries Act Chapter 378. (Revised Edition 2012). Retrieved from Kenya Law Reporting Website: www.kenyalaw.org.

Corley, T. A. (1990). Emergence of the Theory of Industrial Organization, 1890-1990. Business and Economic History, 19:83-92.

Freeman, R. E., Gilbert, D. R., \& Stoner, J. A. (2009). Management (6th Ed.). India: Prentice Hall.

Jaeckel, A., \& Ngige, Z. N. (2007). Case Study Report: Kenya Fisheries Regulations 2007 (Report No.6). Retrieved from International Development Law Organization website: http://www.idlo.int 
Johnson, G., Scholes, K., \& Whittington, R. (2011). Exploring Corporate Strategies (7 $7^{\text {th }}$ Ed.). India:Pearson.

Kotler, P. (2006). Marketing Management (12 ${ }^{\text {th }}$ Ed.). India: Prentice Hall.

Lynch, R. (2009). Strategic Management ( $5^{\text {th }}$ Ed.). India: Prentice Hall.

Mazzarol, T., \& Rebound, S. (2009). The Strategy of Small Firms: Strategic Management and Innovation in the Small Firm. USA: Edward Elgar.

Mintzberg, H., \& Waters, J. A. (1985). Of Strategies, Deliberate and Emergent. Strategic Management Journal, 6(3):257-272.

Mital, A., Pearce, J.A., \& Robinson, R.B. (2011). Strategic Management: Formulation, Implementation and Control (12 ${ }^{\text {th }}$ Ed.). India: McGraw-Hill.

Mugenda, A. G., \& Mugenda, O. M. (1999). Research Methods: Quantitative and Qualitative Approaches. Nairobi: ACTS Press.

Pearce, J. A., \& Robinson, R. B. (2011). Strategic management: Formulation, Implementation and

Control (12 ${ }^{\text {th }}$ Ed.). India: McGraw-Hill.

Porter, M. E. (1980). Competitive Strategy. New York: Free Press.

Porter, M. E. (1985). Competitive advantage: Creating and Sustaining Superior Performance. New York: Free Press.

Porter, M. E. (1996). What is Strategy? Harvard Business Review, 74(6): 61-78.

The Fisheries (Beach Management Unit) Regulations, 2007, Legal Notice No. 402 (2010).

Government of Kenya (2010). Agricultural Sector Development Strategy 2010-2020. Nairobi: Government Printer.

Government of Kenya (2011). District Environment Action Plan Bondo District 2006-2011. Bondo: District Environment Officer. 